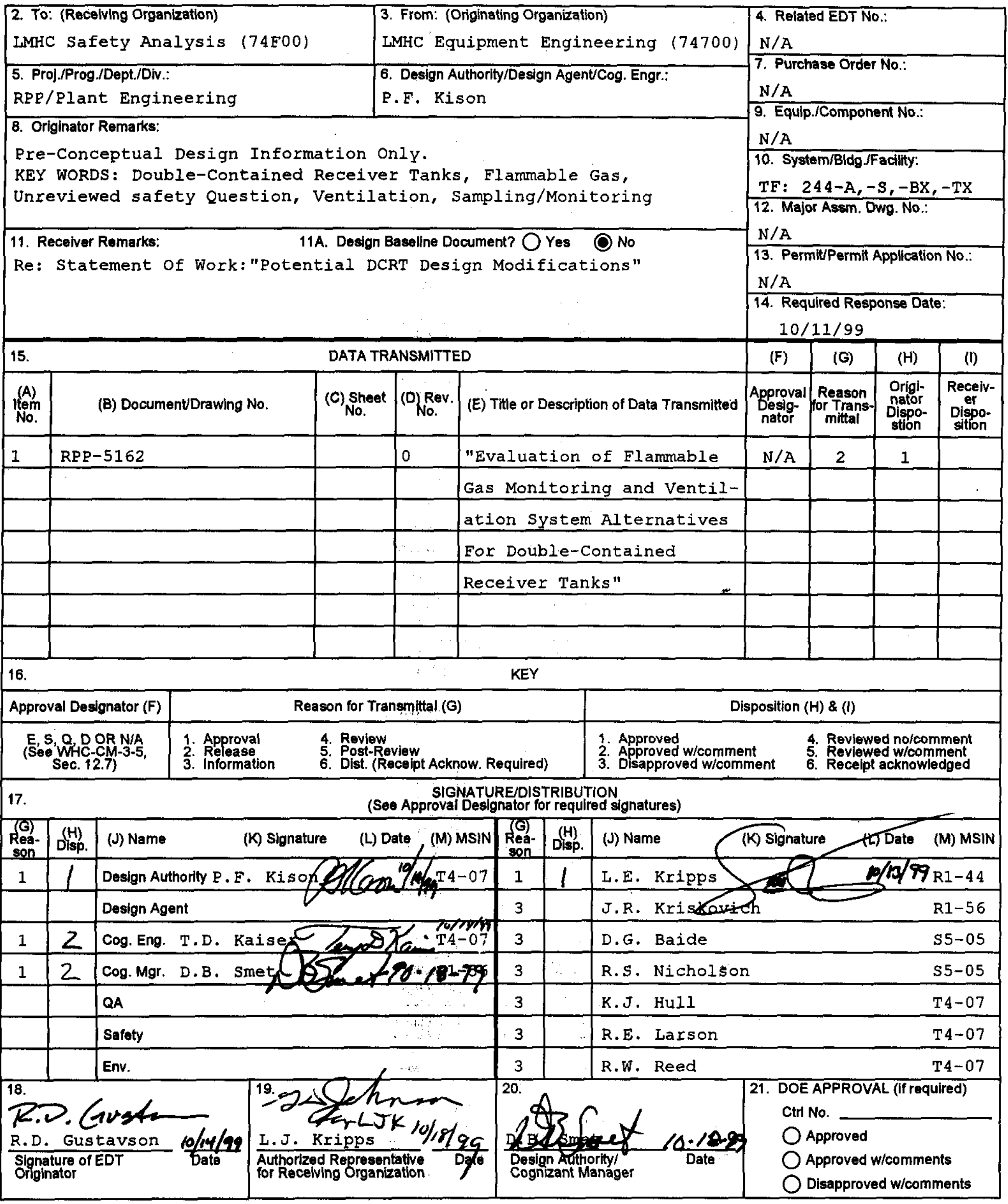




\title{
Evaluation Of Flammable Gas Monitoring and Ventilation System Alternatives For Double-Contained Receiver Tanks
}

\author{
RD Gustavson (JKB 10119199)
}

Lockheed Martin Hanford Corporation

River Protection Project

Richland, WA 99352

U.S. Department of Energy Contract DE-AC06-96RL13200

$\begin{array}{ll}\text { EDT/ECN: } 627784 & \text { UC: } \\ \text { Org Code: } 74700 & \text { Charge Code: } 101919 / \text { HMLM O231 } \\ \text { B\&R Code: } & \text { Total Pages: } 31 \text { (JKB (O) } 19 \text { (99) }\end{array}$

Key Words: Double-Contained Receiver Tank (DCRT), Flammable Gas, Unreview ed Safety Question (USQ), Ventilation, Sampling, Monitoring.

\begin{abstract}
:
This study identifies possible flammable gas monitoring and ventilation system alternatives to ensure adequate removal of flammable gases from the Double-Contained Receiver Tank (DCRT) primary tanks during temporary storage of small amounts of waste. The study evaluates and compares these alternatives to support closure of the Flammable Gas Unreviewed Safety Question (USQ TF-96-04330).
\end{abstract}

TRADEMARK DISCLAIMER. Reference herein to any specific commercial product, process, or service by trade name, trademark, manufacturer, or otherwise, does not necessarily constitute or imply its endorsement, recommendation. or favoring by the United States Government or any agency thereof or its contractors or subcontractors.

Printed in the United States of America. To obtain copies of this document, contact: Document Control Services, P.O. Box 950, Mailstop H6-08, Richland WA 99352, Phone (509) 372-2420; Fax (509) 376-4989.
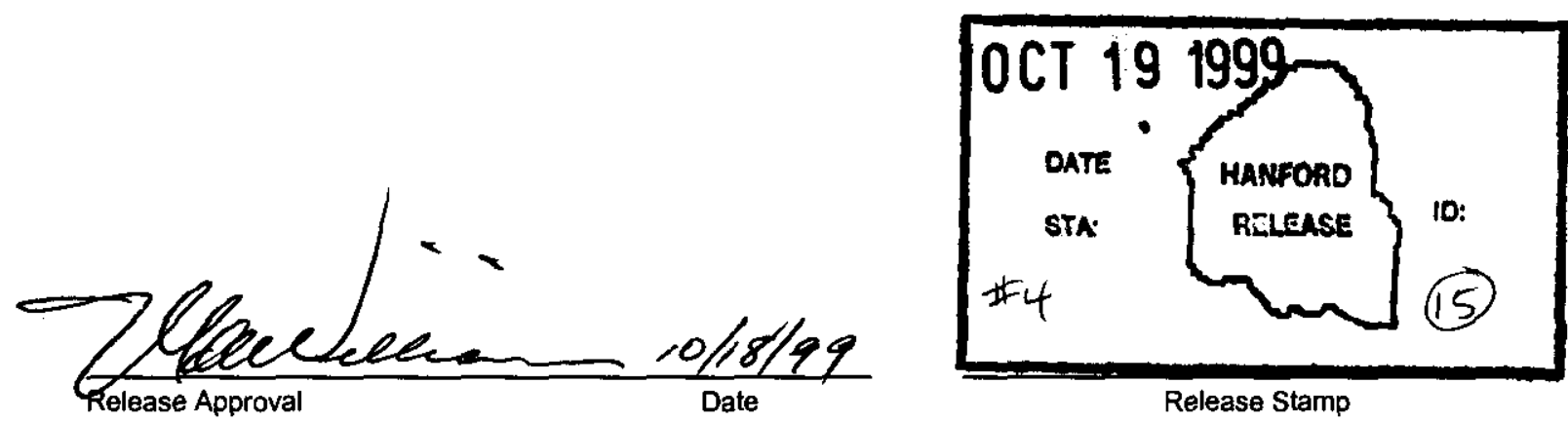

Approved For Public Release 


\title{
EVALUATION OF FLAMMABLE GAS MONITORING AND VENTILATION SYSTEM ALTERNATIVES FOR DOUBLE-CONTAINED RECEIVER TANKS
}

\author{
Prepared by \\ Lockheed Martin Hanford Corporation \\ Equipment Engineering
}

October 18, 1999 


\section{TABLE OF CONTENTS}

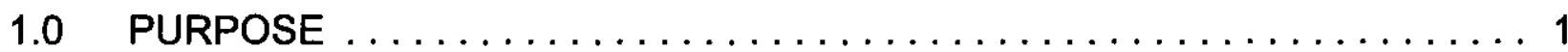

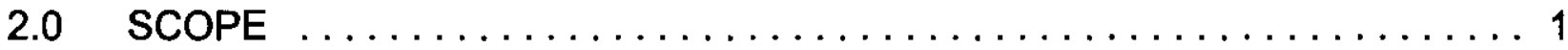

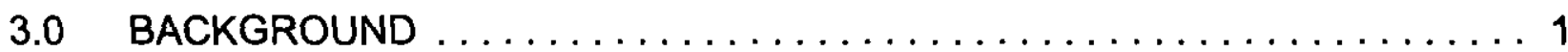

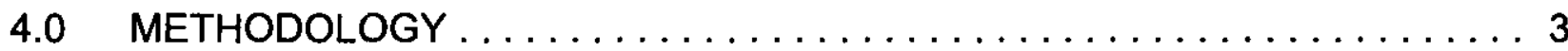

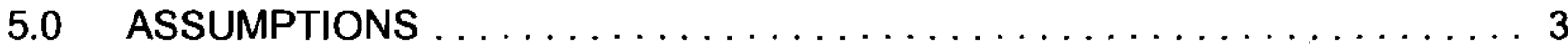

6.0 EVALUATED ALTERNATIVES $\ldots \ldots \ldots \ldots \ldots \ldots \ldots \ldots \ldots \ldots \ldots$

6.1 Alternative \#1: Install Sample Probes and Connections for

6.2 Alternative \#2: Install SHMS for Continuous Monitoring of Tank Vapor Space ................. 5

6.3 Alternative \#3: Provide Flow Monitor in the Tank Exhaust Duct . . . 5

6.4 Alternative \#4: Install New Inlet Filter for the Primary Tank . . . . 6

6.5 Alternative \#5: Install New Inlet Filter plus SHMS Unit ........6 6

6.6 Alternative \#6: Install Portable Exhauster with New Inlet Filter ... . 6

6.7 Alternative \#7: Install Portable Exhauster with New Inlet Filter Plus SHMS Unit $\ldots \ldots \ldots \ldots \ldots \ldots \ldots \ldots$

7.0 EVALUATION ................................ 7

7.1 Cost Evaluation and Comparison $\ldots \ldots \ldots \ldots \ldots \ldots \ldots \ldots \ldots$

7.2 Schedule (Duration) Comparison $\ldots \ldots \ldots \ldots \ldots \ldots \ldots \ldots \ldots$

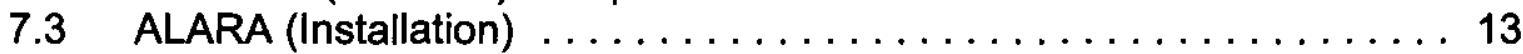

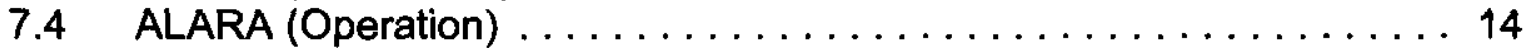

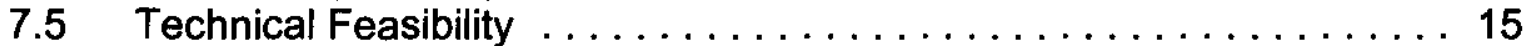

7.6 Operability and Maintainability $\ldots \ldots \ldots \ldots \ldots \ldots \ldots \ldots \ldots$

8.0 SUMMARY AND CONCLUSIONS $\ldots \ldots \ldots \ldots \ldots \ldots \ldots \ldots \ldots$

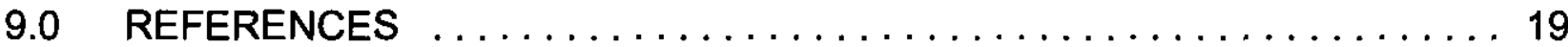

Appendix A: Figures 


\section{ABBREVIATIONS AND ACRONYMS}

ALARA

CGM

DCRT

FGM

HEPA

LFL

ROM

scfm

scfh

SHMS

SST

USQ as low as reasonably achievable

combustible gas monitor

double-contained receiver tank

flammable gas monitor

high efficiency particulate air (filter)

lower flammability limit

rough order of magnitude

standard cubic feet per minute

standard cubic feet per hour

standard hydrogen monitoring system

single-shell tank

unreviewed safety question 


\subsection{PURPOSE}

This study was established to identify possible flammable gas monitoring and ventilation system alternatives to ensure adequate removal of flammable gases from the Double-Contained Receiver Tank (DCRT) primary tanks during temporary storage of small amounts of waste. The study evaluates these alternatives to support closure of the Flammable Gas Unreviewed Safety Question (USQ TF-96-04330) for the DCRTs. A preliminary decision analysis process is used to compare and analyze the alternatives.

\subsection{SCOPE}

The DCRTs applicable to this study are those contained within the 244-A, -BX, $-S$, and TX vault structures. The tank in the 244-A Lift Station vault has never been used as a waste transfer receiver tank, but because it has that capability it is identified as a DCRT. The tank has served the function of a secondary containment catch tank for the waste transfer jumper arrangements in the 244-A pump pit.

The 244-U and 244-CR vault units are not within the scope of this study. DCRT 244-U has never held waste, and it has recently been determined to not hold a future mission for providing waste transfer and storage capability. The 244-CR vault contains one tank (Tank 241-CR-003) that has been identified as a DCRT based on its potential use for saltwell pumping of interstitial liquid waste from 241-C Tank Farm tanks (e.g., Tank 241-C-103). However, because of the uncertainty associated with its future use, Tank 244-CR-003 is not included in the scope of this study.

\subsection{BACKGROUND}

The DCRTs were designed to receive and provide temporary storage for relatively small amounts of waste during transfers from single shell tank (SST) farms and other facilities (e.g., Plutonium Finishing Plant, REDOX, etc.) to double shell tank farms. The tanks have a maximum capacity of 31,000 gallons. The DCRTs have active ventilation systems which provide a combined minimum flow rate of 160 standard cubic feet per minute $(\mathrm{scfm})$ to the tank and surrounding annulus space during waste transfers.

There is currently no means of directly and continuously measuring the primary tank exhaust flow, as the stream is combined with the annulus exhaust stream prior to the present point of effluent flow measurement. The air is drawn from the primary tank into the main ventilation header in the filter pit where it is combined with the ventilation air flow from the annulus space. Because exhaust from the primary tank and annulus are combined at the main header in the filter pit prior to flow measurement point, the actual flow rate from the primary tank cannot be measured independently of the annulus flow. 
Currently, air flow through the DCRT primary tanks is provided at a rate of 3.0 (minimum) to 7.5 standard cubic feet per hour $(0.50$ to $0.125 \mathrm{scfm})$ via dip tube purge air. This flow input is measured via rotometers and is recorded every 12 hours through surveillance rounds. Additionally, certain undefined sources of air infiltration to the primary tank exist (uncapped inlet nozzles, riser flanges, etc.) which allow more airflow to be pulled through the tank by the exhauster. This air infiltration was confirmed in a series of vapor space sampling events in the summer of 1998 (Bauer 1998) which measured the decay rate of injected tracer gas to estimate the actual tank ventilation (or breathing) rate. The results indicate nominal ventilation rates of: 0.45 cubic feet per minute $(\mathrm{cfm})$ for $244-\mathrm{TX} ; 14.0 \mathrm{cfm}$ for $244-\mathrm{S} ; 7.6 \mathrm{cfm}$ for $244-\mathrm{A}$; and $0.7 \mathrm{cfm}$ for $244-\mathrm{BX}$ (Bauer/Hedengren 1999).

The dip tube purge air flow rate is approved as providing adequate flow for flammable gas control in the Basis for Interim Operation (BIO), but the closure of the Flammable Gas USQ requires re-evaluating the basis and adequacy of this control and determining whether there are other alternatives or additional actions necessary to further reduce the risk of flammable gas. Using a tank ventilation flow rate of $3 \mathrm{cfh}$, calculations based upon tank waste characterization data and empirically based models (Hedengren, et.al., 1997) have predicted that flammable gas concentrations in the dome space of a DCRT are below $25 \%$ of the LFL for waste feed flow rates of up to 4 gallons per minute (gpm) from saltwell pumping operations of SSTs, with the exception of four tanks: 241-SX$101,241-S X-103,241-S X-105$, and 241-U-106. For these tanks, alternate calculations predict levels below $25 \%$ of the LFL using operational controls such as limiting a DCRT to $50 \%$ of its capacity, restricting feed flow to $2 \mathrm{gpm}$, and/or requiring a ventilation flow rate of at least $5 \mathrm{cfh}$.

During SST interim stabilization saltwell pumping activities, the transfer source tank is monitored in the saltwell pit for flammable gas concentration. If the SST from which waste is being transferred to the DCRT exceeds $25 \%$ of the LFL, the pumping is stopped. To date, there have been no SSTs that have come close to that limit. The potential for flammable gas generation through mechanisms such as waste transfers, radiolysis, thermal degradation of organic material, and corrosion of tank materials is calculated to be significantly lower than the tank air flow provided, but due to large uncertainty these calculations are being re-visited.

The effectiveness of the primary tank ventilation system in maintaining flammable gas inventory within acceptable limits is currently not determined through direct measurement means, as there are no installed monitoring systems for measurement of flammable gas concentrations within the DCRT primary tank head spaces. Modifications that enhance the ability to periodically or continuously sample and monitor flammable gas concentrations within the tank vapor space [e.g., installation of a Standard Hydrogen Monitoring System (SHMS)] and/or improvements in the DCRT ventilation system capabilities could further reduce the risk of flammable gas hazard in the DCRTs if current controls are deemed inadequate. 


\subsection{METHODOLOGY}

The selection of alternatives was done by engineering evaluation of the existing systems to identify improvements that are technically possible to implement.

Flammable gas concentrations within the DCRT tanks are required to be maintained below $25 \%$ of the Lower Flammability Limit (LFL). Demonstration in satisfying this requirement can be improved to varying degree through one or more of the following actions:

- Monitoring of the flammable gas concentration within the primary tank head space.

- $\quad$ Enhanced primary tank exhaust flow measurement capability.

- Increased air flow through the primary tank.

Selected flammable gas monitoring and/or ventilation system modification alternatives are packaged to meet one or more of these functions. Seven alternatives are presented using a graded approach to modifications, component installations, and their combinations.

An evaluation was conducted to compare the selected alternatives in relation to the following criteria:

- Cost

- Schedule (duration)

- ALARA Concerns

- Technical Feasibility

- Operability and Maintainability.

The results of this study will be used to recommend possible design modifications to DCRTs to support closure of the Flammable Gas USQ if necessary.

\subsection{ASSUMPTIONS}

Some basic assumptions are made regarding the selection and evaluation of alternatives in this study, including the following:

- It is assumed that the information in this study will be used as part of a formal controlled decision or alternative generation analysis process, should present DCRT operational methods be insufficient for satisfactory closure of the flammable gas USQ.

- It is assumed that DCRT mission and service life will be considered as a major factor if and when formal decision processes occur.

- This document presents only rough order of magnitude cost information and upper level estimated schedule durations. It is assumed that formal and detailed cost and schedule information for the identified alternatives will be developed at a later date to support further alternative analysis and decision processes. 
- This document considers elements of design, procurement, fabrication, and installation of system alternatives. Life cycle costs for operation, maintenance, closure, etc., are not addressed. It is assumed that formal selection processes will consider and weigh the life cycle costs of evaluated alternatives.

- It is assumed that SHMS units are available for installation to provide periodic or continuous monitoring functions.

\subsection{EVALUATED ALTERNATIVES}

Alternatives considered are described in the following sections. Block diagrams of the identified alternatives are found as figures in Appendix A. The block diagrams are intended to represent general configurations only, not explicit design.

It is important to note that the subject tanks and their supporting vaults and pits are of two different fundamental designs: DCRTs (244-BX and -TX) and Lift Stations (244-A and -S). DCRTs 244-BX and 244-TX have available risers at existing grade that directly penetrate the tank vapor space while bypassing the pump pit. Providing access to the tank vapor space is more complicated for the lift stations than for the DCRTs, because direct tank penetrations from grade do not exist. For the lift stations, available tank penetrations are primarily located in the pump pit and consist of spare 3-inch tank and vault wall penetration nozzles without the necessary existing jumpers. External access to those tank spaces from ground level will require substantially more work, including jumper fabrication, excavation, core drilling, welding, cover block removal, etc. For the purposes of periodic sampling, sample withdrawal from the head spaces of the tanks could be achieved through the existing dip tube system, but sample return is a complication.

\subsection{Alternative \#1: Install Sample Probes and Connections for Periodic Vapor Space Sampling/Monitoring.}

Determination of the effectiveness of periodic sampling and monitoring, especially before, during, and after waste disturbing operations, may preclude any need to conduct continuous monitoring for flammable gas of the DCRTs. Periodic sampling/monitoring should be considered as a method for addressing the flammable gas issue should the other alternatives be unacceptable.

Alternative \#1 maintains the existing ventilation system which is currently in use to ventilate both the primary tank and annulus spaces, but provides access capability for periodic vapor sampling/monitoring of the tank vapor space for flammable gas concentrations using existing tank penetrations (see Figure \#1 in Appendix A). This alternative would install both the necessary probes and/or sample lines through tank penetrations and the above-ground connections for attachment and use of a Combustible Gas Monitor (CGM), Flammable Gas Monitor (FGM), or portable SHMS unit at 
a periodicity to be determined based upon the operational uses of each specific DCRT.

Determination of the frequency of periodic sampling/monitoring necessary to address potential flammable gas concerns is not in the scope of this paper, but this alternative was selected for evaluation in consideration of a graded approach to sampling/monitoring during waste disturbing operations such as waste transfer during Single-Shell tank (SST) saltwell pumping. This graded approach is envisioned to be similar to the flammable gas concentration periodic monitoring scheme in Administrative Control 5.11.2 (b) (2) of HNF-SD-WM-TSR-006, Tank Waste Remediation System Technical Safety Requirements (Noorani, 1998), for SST dome spaces and pump pits used during saltwell pumping. The referenced scheme for SSTs requires periodic monitoring for longduration operations (e.g., saltwell pumping) to be accomplished once per hour for 5 hours, then once per day for three days, then once per week, assuming the monitored flammable gas concentration remains below predefined levels.

\subsection{Alternative \#2: Install SHMS for Continuous Monitoring of Tank Vapor Space}

Alternative \#2 installs a Standard Hydrogen Monitoring System (SHMS) to directly and continuously monitor the flammable gas concentration within the tank vapor space (see Figure \#2, Appendix A). This alternative includes the fixed installation and connection of a SHMS unit, along with sample withdrawal and return configurations.

In identification of this alternative, installation and use of a SHMS unit was preferred over a FGM for a number of reasons. As stated above, SHMS units are available, thereby saving procurement costs. Procurement costs of a FGM are about the same as the removal costs of an existing SHMS unit. SHMS have much more capability than a FGM in qualifying and quantifying constituent gases. Also, the reliability, operability, and maintainability of SHMS have been proven through extensive use at tank farms. A SHMS spare parts program is active, and operations and maintenance procedures are fully developed.

\subsection{Alternative \#3: Provide Flow Monitor in the Tank Exhaust Duct}

Alternative \#3 installs a flow measuring element in the exhaust duct from the primary tank (see Figure \#3, Appendix A). This alternative would provide the capability of measuring the actual primary exhaust flow rate, thereby providing the supporting flow data for both the analyses of the effectiveness of tank breathing rates in removing flammable gasses and 
RPP-5162, Rev. 0

the operational adjustment of annulus and primary flow rates.

\subsection{Alternative \#4: Install New Inlet Filter for the Primary Tank}

Alternative \#4 adds a new engineered inlet filter to the primary tank to increase the flow inlet capacity to the primary tank, and hence the flowrate through the tank space. Ventilation flow to the primary tank would be measured on the intake system to ensure the necessary minimum flow is maintained. A block diagram representation of the alternative is shown in Figure \#4 of Appendix A.

\subsection{Alternative \#5: Install New Inlet Filter plus SHMS Unit}

Alternative \#5 will install a SHMS unit in addition to the new inlet filter of Alternative \#4 (see Figure \# 5, Appendix A). This alternative would provide both increased air flow capability through the primary tank and the capability to monitor flammable gas concentration within the tank vapor space.

\subsection{Alternative \#6: Install Portable Exhauster with New Inlet Filter}

Alternative \#6 adds a portable exhauster and new inlet filter to the primary tank ventilation path and closes the manual valve on the existing flow path from the primary tank to the existing filter train (see Figure \#6, Appendix A). The new inlet filter would increase the flow inlet capacity to the primary tank, and hence the flowrate through the tank space. The separate portable exhauster and exhaust filter train for the primary ventilation stream would have the effect of maintaining separation from the annulus ventilation stream; thus, flow measurement and flow control of each stream could be accomplished independently.

\subsection{Alternative \#7: Install Portable Exhauster with New Inlet Filter Plus SHMS Unit}

This alternative will install the portable exhauster and inlet filter system of Alternative \#6, and it will install a SHMS unit on the tank exhaust stream. This would provide increased air flow through the tank, independent flow measurement and flow control for both the primary and annulus ventilation streams, and continuous flammable gas concentration measurement for the primary tank. 


\subsection{EVALUATION}

The alternatives were evaluated and ranked relative to each other for each of six decision criteria. The alternatives are given a score of 1 through 7 for each criteria, with 7 being the highest score. Weight factor multipliers were then applied to each of the decision criteria to emphasize its relative importance. These criteria are:

- Cost: $(25 \%$ weight factor $)$

A simplified cost comparison was performed for the alternatives. Rough order of magnitude (ROM) estimates were developed from a combination of formal estimates, plant experience, and engineering judgement. Cost estimates were based on engineering and associated field work (modifications) required to install the specific alternative system. The alternatives are ranked ( 1 through 7 ) relative to each other.

- Schedule (duration): ( $15 \%$ weight factor)

A comparison of alternatives was performed for ability to implement in terms of time or duration. This criterion is important because of its relationship to both the remaining mission life of each of the DCRTs and the ability to compete with other work evolutions for the necessary human resources. Included in the duration time are all the elements (design, procurement, installation, procedure development, start-up testing, readiness review, etc.) necessary for the alternative systems to become operational. The alternatives are ranked relative to each other for this criterion.

- $\quad$ ALARA (Installation): (10\% weight factor)

A comparison was performed between the various installation activities in regards to potential radiation exposure to construction crews. The alternatives are ranked relative to each other.

- ALARA (Operation): (10\% weight factor)

A comparison was performed between the various operational activities in regards to potential radiation exposure to operators and maintenance crews.

- Technical Feasibility: ( $20 \%$ weight factor)

This criterion includes a comparison of the technical feasibility for each alternative with respect to complexity of design and field installation. Certain alternatives will require new designs and fabrications, while others will make use of existing and proven designs. The alternatives are ranked ( 1 through 7$)$ in relation to each other. 
RPP-5162, Rev. 0

- Operability \& Maintainability: ( $20 \%$ weight factor)

This criterion includes a comparison of the operations and maintenance load resulting from installation of the various alternatives. Operability and maintainability can be assessed by the complexity of access, testing, reliability, and repair ability of the associated systems and components.

The performance of each alternative was evaluated with respect to each decision criteria and in relation to the other alternatives. Each of these scores in turn has a weight factor applied to emphasize the importance of the criteria. The total score for each alternative is the summation of the scores for each evaluation criterion.

\subsection{Cost Evaluation and Comparison}

A cost comparison was performed between the selected alternatives. ROM cost estimates were developed for each alternative which focused on two major areas: construction costs and engineering costs. Included within these two major areas are design, review, procurement, fabrication, testing, installation, operations/maintenance procedures, and operational acceptance. These cost estimates assume that substantial contamination exists in the DCRT pump and filter pits.

For the purposes of this document, it is assumed that the selected alternative will be applied to all four DCRT units; therefore, a single average cost is provided for each alternative Because of design differences between the DCRT units primarily associated with tank accessability and penetration availability, costs for one type of DCRT are substantially different than for another for most of the alternatives.

Comparison and scoring of the alternative costs is presented in Table 1. The scoring system is intentionally kept simple and unsophisticated. The alternatives are given a score of 1 through 7 , with 7 being the most preferential score. $A$ weight factor of $25 \%$ was then applied to the scores to attach the appropriate importance to this criterion in relation to the other criteria. 


\begin{tabular}{|c|l|l|c|c|}
\hline \multicolumn{5}{|c|}{ Table 1: Cost Evaluation and Ranking } \\
\hline $\begin{array}{c}\text { Alternative } \\
\text { Number }\end{array}$ & \multicolumn{1}{|c|}{ System Description } & $\begin{array}{l}\text { Cost Per } \\
\text { Unit }\end{array}$ & $\begin{array}{c}\text { Ranking } \\
\text { Score }\end{array}$ & $\begin{array}{c}\text { Weighted } \\
\text { Score }\end{array}$ \\
\hline 1 & $\begin{array}{l}\text { Install Capability for Periodic } \\
\text { Monitoring of Tank Vapor Space }\end{array}$ & $\begin{array}{l}\$ 65 \mathrm{~K} \\
\text { (avg/unit) }\end{array}$ & 7 & 1.75 \\
\hline 2 & Install SHMS to Tank Vapor Space & $\begin{array}{l}\$ 270 \mathrm{~K} \\
\text { (avg/unit) }\end{array}$ & 4 & 1.00 \\
\hline 3 & $\begin{array}{l}\text { Install Flow Monitor Device on Tank } \\
\text { Exhaust }\end{array}$ & $\begin{array}{l}\$ 180 \mathrm{~K} \\
\text { per unit }\end{array}$ & 6 & 1.50 \\
\hline 4 & $\begin{array}{l}\text { Install New Inlet Filter System for } \\
\text { Tank }\end{array}$ & $\begin{array}{l}\$ 210 \mathrm{~K} \\
\text { (avg/unit) }\end{array}$ & 5 & 1.25 \\
\hline 5 & $\begin{array}{l}\text { Install New Inlet Filter System for } \\
\text { Tank PLUS Install SHMS to Tank } \\
\text { Vapor Space }\end{array}$ & $\begin{array}{l}\$ 480 \mathrm{~K} \\
\text { (avg/unit) }\end{array}$ & 3 & 0.75 \\
\hline 6 & $\begin{array}{l}\text { Install Portable Exhauster with New } \\
\text { Inlet Filter }\end{array}$ & $\begin{array}{l}\$ 860 \mathrm{~K} \\
\text { (avg/unit) }\end{array}$ & 2 & 0.50 \\
\hline 7 & $\begin{array}{l}\text { Install Portable Exhauster with New } \\
\text { Inlet Filter PLUS Install SHMS to } \\
\text { Exhaust Stream }\end{array}$ & $\begin{array}{l}\$ 1,090 \mathrm{~K} \\
\text { (avg/unit) }\end{array}$ & 1 & 0.25 \\
\hline
\end{tabular}

Alternative \#1 scored the highest for this decision criteria as a result of having the lowest cost for implementation. Costs for 244-BX and 244-TX are estimated to be $\$ 50 \mathrm{~K}$ per unit. Costs for $244-\mathrm{A}$ and $244-\mathrm{S}$ are estimated to be $\$ 80 \mathrm{~K}$ per unit because of increased complexity of design work and sample line connections on these units. Average unit cost for implementation of this alternative is $\$ 65 \mathrm{~K}$.

Alternative \#3 scored second highest at an estimated cost of $\$ 180 \mathrm{~K}$. This alternative makes use of an existing design for a flow measurement device, yet it requires jumper fabrication and entry into highly contaminated filter pits.

Alternative \#4 scored third highest for the cost decision criteria. Average estimated unit cost for this alternative is $\$ 210 \mathrm{~K}$. Costs for 244-BX and 244-TX are estimated to be $\$ 160 \mathrm{~K}$ per unit utilizing an existing inlet filter design (244-U inlet filter) and existing tank penetrations accessible at grade level. Costs for 244-A and 244-S (\$260K per unit) are estimated to be substantially more because increased design work, excavation, jumper fabrication, welding, and pit entry are required to configure a system which provides a grade level inlet filter and tank inlet ductwork while not restricting future pump pit cover block removal. 
Alternative \#2 scored fourth highest for this decision criteria at an average estimated unit cost of $\$ 270 \mathrm{~K}$. These estimates include the work to remove and make available existing SHMS units in the field ( $\$ 70 \mathrm{~K} /$ unit). Costs for 244-BX and $244-\mathrm{TX}$ are estimated to be $\$ 220 \mathrm{~K}$ per unit utilizing existing tank penetrations accessible at grade level. Costs for $244-\mathrm{A}$ and $244-\mathrm{S}$ (\$320K per unit) are estimated to be substantially more because increased design work, excavation, jumper fabrication, welding, and pit entry are required to configure a system which provides grade level access (and sample return) for continuous tank vapor space sample withdrawal on these units.

Alternative \#5 scored fifth highest of the seven alternatives at an average estimated cost of $\$ 480 \mathrm{~K}$. This alternative combines the elements of Alternatives \#2 and \#4. Costs for 244-BX and 244-TX are estimated to be $\$ 380 \mathrm{~K}$ per unit utilizing existing direct tank penetrations accessible at grade level. Costs for 244-A and 244-S ( $\$ 580 \mathrm{~K}$ per unit) are estimated to be substantially more because increased design work, excavation, jumper fabrication, welding, and pit entry are required.

Alternative \#6 scored sixth for the cost criteria at an average estimated cost of $\$ 860 \mathrm{~K}$. This alternative combines the elements of Alternative \#4 (new inlet filter) with the installation of a portable exhauster and exhaust filter bank. Costs for 244-BX and 244-TX are estimated to be $\$ 760 \mathrm{~K}$ per unit utilizing existing direct tank penetrations accessible at grade level. Costs for 244-A and 244-S (\$960K per unit) are estimated to be substantially more because increased design work, excavation, jumper fabrication, welding, and pit entry are required.

Alternative \#7 scored lowest among the alternatives for the cost criteria at an average estimated cost of $\$ 1090 \mathrm{~K}$. This alternative combines the elements of Alternative \#6 (new inlet filter and portable exhauster) with the installation of a available SHMS unit on the exhaust duct. Costs for 244-BX and 244-TX are estimated to be $\$ 980 \mathrm{~K}$ per unit utilizing existing direct tank penetrations accessible at grade level. Costs for 244-A and 244-S (\$1200K per unit) are estimated to be substantially more because increased design work, excavation, jumper fabrication, welding, and pit entry are required.

\subsection{Schedule (Duration) Comparison}

The alternatives were compared regarding the duration of time necessary for implementation. Evolution durations were estimated which included design, procurement, fabrication and testing, installation, procedure development, and acceptance testing. During schedule estimation, credit was taken for accomplishment of concurrent activities (e.g., design, procurement, etc.) where identified.

It is assumed that the selected alternative will be applied to all four DCRT units; therefore, a single average duration is provided for each alternative 
Because of design differences between the DCRT units primarily associated with tank accessability and penetration availability, schedule duration for one type of DCRT may be substantially different than for another.

Comparison and scoring of the alternative overall schedule durations is presented in Table 2 below. The scoring system is intentionally kept simple and unsophisticated. The alternatives are given a score of 1 through 7 , with 7 being the most preferential score. A weight factor of $15 \%$ was then applied to the scores to attach the appropriate importance to this criterion in relation to the other criteria.

\begin{tabular}{|c|l|c|c|c|}
\hline \multicolumn{5}{|c|}{ Table 2: Schedule (Duration) Evaluation and Ranking } \\
\hline $\begin{array}{c}\text { Alternative } \\
\text { Number }\end{array}$ & \multicolumn{1}{|c|}{ System Description } & Duration & $\begin{array}{c}\text { Ranking } \\
\text { Score }\end{array}$ & $\begin{array}{c}\text { Weighted } \\
\text { Score }\end{array}$ \\
\hline 1 & $\begin{array}{l}\text { Install Capability for Periodic } \\
\text { Monitoring of Tank Vapor Space }\end{array}$ & $\begin{array}{l}3.3 \mathrm{mo} . \\
\text { (avg/unit) }\end{array}$ & 7 & 1.05 \\
\hline 2 & Install SHMS to Tank Vapor Space & $\begin{array}{l}9.0 \mathrm{mo} . \\
\text { (avg/unit) }\end{array}$ & 4 & 0.60 \\
\hline 3 & $\begin{array}{l}\text { Install Flow Monitor Device on Tank } \\
\text { Exhaust }\end{array}$ & $\begin{array}{l}6.0 \mathrm{mo} . \\
\text { per unit }\end{array}$ & 5 & 0.75 \\
\hline 4 & $\begin{array}{l}\text { Install New Inlet Filter System for } \\
\text { Tank }\end{array}$ & $\begin{array}{l}5.8 \mathrm{mo} . \\
\text { (avg/unit) }\end{array}$ & 6 & 0.90 \\
\hline 5 & $\begin{array}{l}\text { Install New Inlet Filter System for } \\
\text { Tank PLUS Install SHMS to Tank } \\
\text { Vapor Space }\end{array}$ & $\begin{array}{l}12.5 \mathrm{mo} . \\
\text { (avg/unit) }\end{array}$ & 3 & 0.45 \\
\hline 6 & $\begin{array}{l}\text { Install Portable Exhauster with New } \\
\text { Inlet Filter }\end{array}$ & $\begin{array}{l}14.0 \mathrm{mo} . \\
\text { (avg/unit) }\end{array}$ & 2 & 0.30 \\
\hline 7 & $\begin{array}{l}\text { Install Portable Exhauster with New } \\
\text { Inlet Filter PLUS Install SHMS to } \\
\text { Exhaust Stream }\end{array}$ & $\begin{array}{l}15.0 \mathrm{mo} . \\
\text { (avg/unit) }\end{array}$ & 1 & 0.15 \\
\hline
\end{tabular}

Alternative \#1 scored the highest for this decision criteria as a result of having the shortest duration of schedule. Schedule duration for 244-BX and 244-TX is estimated to be 2.5 months per unit. Schedule duration for 244-A and 244-S (4 months per unit) is estimated to be slightly longer because of increased complexity of design work and sample line connections on these units. Unit average schedule duration for implementation of this alternative is $\mathbf{3 . 3}$ months.

Alternative \#4 scored second highest for the schedule decision criteria. Average 
estimated schedule duration for this alternative is $\mathbf{5 . 8}$ months per unit. Schedule duration for 244-BX and 244-TX is estimated to be 4.0 months per unit utilizing existing tank penetrations accessible at grade level. Schedule duration for 244-A and 244-S (7.5 months per unit) is estimated to be substantially more because increased design work, excavation, jumper fabrication, welding, and pit entry are required to configure a system which provides a grade level inlet filter and tank inlet ductwork while not restricting future pump pit cover block removal.

Alternative \#3 scored third highest at an estimated duration of $\mathbf{6 . 0}$ months per unit. This alternative makes use of an existing design for a flow measurement device, yet it requires jumper fabrication and entry into highly contaminated filter pits.

Alternative \#2 scored fourth highest for this decision criteria at an average estimated unit schedule duration of $\mathbf{9 . 0}$ months. These schedule estimates include the work to remove and make available existing SHMS units in the field. Schedule durations for 244-BX and 244-TX are estimated to be 6.5 months per unit utilizing existing tank penetrations accessible at grade level. Schedule durations for 244-A and 244-S (11.5 months per unit) are estimated to be substantially more because increased design work, excavation, jumper fabrication, welding, and pit entry are required to configure a system which provides grade level access (and sample return) for continuous tank vapor space sample withdrawal on these units.

Alternative \#5 scored fifth highest of the seven alternatives at an average estimated schedule duration of $\mathbf{1 2 . 5}$ months per unit. This alternative combines the elements of Alternatives \#2 and \#4. Schedule durations for 244-BX and 244TX are estimated to be 8.5 months per unit utilizing existing direct tank penetrations accessible at grade level. Schedule duration for 244-A and 244-S (16.5 months per unit) are estimated to be substantially more because increased design work, excavation, jumper fabrication, welding, and pit entry are required.

Alternative \#6 scored sixth for the schedule decision criteria at an average estimated duration of $\mathbf{1 4 . 0}$ months per unit. This alternative combines the elements of Alternative \#4 (new inlet filter) with the installation of a portable exhauster and exhaust filter bank. Schedule durations for 244-BX and 244-TX are estimated to be 10 months per unit utilizing existing direct tank penetrations accessible at grade level. Schedule durations for 244-A and 244-S (18 months per unit) are estimated to be substantially more because increased design work, excavation, jumper fabrication, welding, and pit entry are required.

Alternative \#7 scored lowest among the alternatives for the schedule decision criteria at an average estimated duration of $\mathbf{1 5 . 0}$ months per unit. This alternative combines the elements of Alternative \#6 (new inlet filter and portable exhauster) with the installation of a available SHMS unit on the exhaust duct. Schedule durations for 244-BX and 244-TX are estimated to be 11.0 months per unit utilizing existing direct tank penetrations accessible at grade level. Schedule 
RPP-5162, Rev. 0

durations for 244-A and 244-S (19 months per unit) are estimated to be substantially more because increased design work, excavation, jumper fabrication, welding, and pit entry are required.

\subsection{ALARA (Installation)}

A comparison was performed regarding the relative ability to achieve As Low As Reasonably Achievable (ALARA) conditions during construction or installation of the alternatives. The results of the comparison are presented below in Table 3.

\begin{tabular}{|c|l|c|c|}
\hline \multicolumn{5}{|c|}{ Table 3: ALARA (Installation) Evaluation and Ranking } \\
\hline $\begin{array}{c}\text { Alternative } \\
\text { Number }\end{array}$ & \multicolumn{1}{|c|}{ System Description } & $\begin{array}{c}\text { Ranking } \\
\text { Score }\end{array}$ & $\begin{array}{c}\text { Weighted } \\
\text { Score }\end{array}$ \\
\hline 1 & $\begin{array}{l}\text { Install capability for Periodic Monitoring of } \\
\text { Tank Vapor Space }\end{array}$ & 7 & 0.7 \\
\hline 2 & Install SHMS to Tank Vapor Space & 6 & 0.6 \\
\hline 3 & Install Flow Monitor on Tank Exhaust & 1 & 0.1 \\
\hline 4 & Install New Inlet Filter System for Tank & 5 & 0.5 \\
\hline 5 & $\begin{array}{l}\text { Install New Inlet Filter System for Tank PLUS } \\
\text { Install SHMS Unit to Tank Vapor Space }\end{array}$ & 4 & 0.4 \\
\hline 6 & Install Portable Exhauster with New Inlet Filter & 3 & 0.3 \\
\hline 7 & $\begin{array}{l}\text { Install Portable Exhauster with New Inlet Filter } \\
\text { PLUS Install SHMS Unit to Exhaust Stream }\end{array}$ & 2 & 0.2 \\
\hline
\end{tabular}

Installation of Alternative \#3 would cause the highest potential for exposure to the workers during installation. This alternative would require work to be performed in potentially highly contaminated filter pits. The alternative requires replacement of an existing ventilation jumper in the filter pit with one that includes a flow measurement device.

The other alternatives would all require some access to the pump pit for installation with some exception for DCRTs 244-TX and -BX only, as these units have direct tank penetration risers above grade that bypass the pump pits. While not considered as hazardous as access to the filter pits, high potential for exposure to radioactive material exists in the pump pit areas. For 244-A and 244-S DCRTs, all alternatives (except Alternative \#1 and \#3) would require both installation of jumpers to nozzle tank penetrations in pump pits and excavation around contaminated transfer lines external to the vault walls. Comparison and ranking of these alternatives for potential personnel exposure during installation is based 
upon the complexity of the job and the time required to accomplish.

\subsection{ALARA (Operation)}

A comparison was performed regarding the relative ability to achieve ALARA exposure conditions during operation and maintenance of the alternative systems. Comparison and ranking of these alternatives for potential personnel exposure during operation and maintenance is based upon potential for necessary entry into contaminated pits, the complexity of the system, the number of components requiring maintenance, and the time required to accomplish operational checks/rounds and maintenance activities in the vault radiation areas. The results of the comparison are presented below in Table 4.

\begin{tabular}{|c|l|c|c|}
\hline \multicolumn{3}{|c|}{ Table 4: ALARA (Operational) Evaluation and Ranking } \\
\hline $\begin{array}{c}\text { Alternative } \\
\text { Number }\end{array}$ & \multicolumn{1}{|c|}{ System Description } & $\begin{array}{c}\text { Ranking } \\
\text { Score }\end{array}$ & $\begin{array}{c}\text { Weighted } \\
\text { Score }\end{array}$ \\
\hline 1 & $\begin{array}{l}\text { Install capability for Periodic Monitoring of } \\
\text { Tank Vapor Space }\end{array}$ & 7 & 0.7 \\
\hline 2 & Install SHMS to Tank Vapor Space & 5 & 0.5 \\
\hline 3 & Install Flow Monitor on Tank Exhaust & 1 & 0.1 \\
\hline 4 & Install New Inlet Filter System for Tank & 6 & 0.6 \\
\hline 5 & $\begin{array}{l}\text { Install New Inlet Filter System for Tank PLUS } \\
\text { Install SHMS Unit to Tank Vapor Space }\end{array}$ & 4 & 0.4 \\
\hline 6 & Install Portable Exhauster with New Inlet Filter & 3 & 0.3 \\
\hline 7 & $\begin{array}{l}\text { Install Portable Exhauster with New Inlet Filter } \\
\text { PLUS Install SHMS Unit to Exhaust Stream }\end{array}$ & 2 & 0.2 \\
\hline
\end{tabular}

Alternative \#3 presents the highest risk for exposure to radiation and contamination sources for the workers during operational activities. Flow monitoring devices would be located within the highly contaminated filter pit. Any repair or preventive maintenance activities for these devices after installation would require entry into the filter pit by personnel.

Alternative \#1 presents the lowest risk for exposure of all the alternatives. Virtually no maintenance activities would be required for this system of installed probes, tubing, connections, etc..

Components associated with Alternatives \#2, \#4, \#5, \#6, and \#7 (except ductwork and jumpers in 244-A and 244-S pump pits) are primarily 
located above grade and out of confined spaces that may be contaminated. However Alternatives \#6 and \#7 would require the change out of the portable exhauster train HEPA filters at some point in time. This would potentially expose personnel to contamination and elevated radiation levels during filter change out operations. The filters of Alternatives \#4 and \#5 are on the inlet side and these filters would remain uncontaminated under normal condition. Change out of the inlet filters would not expose personnel to contamination and elevated radiation levels.

\subsection{Technical Feasibility}

A comparison was done between the alternatives for technical feasibility in regards to complexity of design and field installation. The primary constraining factor for feasibility is the availability of tank penetrations (e.g., risers, nozzles, etc.) and their location (e.g., above grade, within pump pit, etc.) The results are presented in Table 5 below.

\begin{tabular}{|c|l|c|c|}
\hline \multicolumn{3}{|c|}{ Table 5: Technical Feasibility Evaluation and Ranking } \\
\hline $\begin{array}{c}\text { Alternative } \\
\text { Number }\end{array}$ & \multicolumn{1}{|c|}{ System Description } & $\begin{array}{c}\text { Ranking } \\
\text { Score }\end{array}$ & $\begin{array}{c}\text { Weighted } \\
\text { Score }\end{array}$ \\
\hline 1 & $\begin{array}{l}\text { Install capability for Periodic Monitoring of } \\
\text { Tank Vapor Space }\end{array}$ & 7 & 1.40 \\
\hline 2 & Install SHMS to Tank Vapor Space & 4 & 0.80 \\
\hline 3 & Install Flow Monitor on Tank Exhaust & 5 & 1.00 \\
\hline 4 & Install New Inlet Filter System for Tank & 6 & 1.20 \\
\hline 5 & $\begin{array}{l}\text { Install New Inlet Filter System for Tank PLUS } \\
\text { Install SHMS to Tank Vapor Space }\end{array}$ & 3 & 0.60 \\
\hline 6 & Install Portable Exhauster with New Inlet Filter & 2 & 0.40 \\
\hline 7 & $\begin{array}{l}\text { Install Portable Exhauster with New Inlet Filter } \\
\text { PLUS Install SHMS to Exhaust Stream }\end{array}$ & 1 & 0.20 \\
\hline
\end{tabular}

Alternatives \#5, \#6, and \#7 ranked the lowest between all of the alternatives. This is primarily because of both the need for additional available risers and the increased size of these two modifications relative to the other alternatives.

Alternative \#3 can make use of an existing engineering design for a flow measurement device in a new ventilation jumper. 
Alternatives \#4 and \#5 could take direct advantage of an existing (244-U inlet filter design) engineering design, however \#5 requires multiple riser availability.

Alternatives \#2, \#5, and \#7 can make use of existing SHMS units, SHMS spare parts, and SHMS spare parts, but provision of sample return to the tank from SHMS units of \#2 and \#5 requires the need for additional tank penetrations. The SHMS unit of Alternative \#7 is envisioned to sample the tank exhaust stream, and therefore would not require additional tank penetration.

\subsection{Operability and Maintainability}

A comparison was done of the alternatives relative to ease of operation and maintenance during operation. Operability and maintainability is assessed by the complexity of access, testing, reliability, and repairability of the associated systems and components. Ranking of the alternatives for this criteria is presented in Table 6 below.

\begin{tabular}{|c|l|c|c|}
\hline \multicolumn{4}{|c|}{ Table 6: Operability and Maintainability Evaluation and Ranking } \\
\hline $\begin{array}{c}\text { Alternative } \\
\text { Number }\end{array}$ & \multicolumn{1}{|c|}{ System Description } & $\begin{array}{c}\text { Ranking } \\
\text { Score }\end{array}$ & $\begin{array}{c}\text { Weighted } \\
\text { Score }\end{array}$ \\
\hline 1 & $\begin{array}{l}\text { Install Capability for Periodic Monitoring of } \\
\text { Tank Vapor Space }\end{array}$ & 7 & 0.70 \\
\hline 2 & Install SHMS to Tank Vapor Space & 5 & 0.50 \\
\hline 3 & Install Flow Monitor on Tank Exhaust & 3 & 0.30 \\
\hline 4 & Install New Inlet Filter System for Tank & 6 & 0.60 \\
\hline 5 & $\begin{array}{l}\text { Install New Inlet Filter System for Tank PLUS } \\
\text { Install SHMS to Tank Vapor Space }\end{array}$ & 4 & 0.40 \\
\hline 6 & Install Portable Exhauster with New Inlet Filter & 2 & 0.20 \\
\hline 7 & $\begin{array}{l}\text { Install Portable Exhauster with New Inlet Filter } \\
\text { PLUS Install SHMS to Exhaust Stream }\end{array}$ & 1 & 0.10 \\
\hline
\end{tabular}

Alternatives \#6 and \#7 scored lowest for operability and maintainability due to the increased complexity and increased number of components requiring scheduled operational checks/readings and preventive maintenance activities.

Alternative \#3 would require entry into highly contaminated filter pits to conduct any corrective maintenance to the flow measurement device or its associated ventilation jumper. 
RPP-5162, Rev. 0

Alternatives \#2, \#4, and \#5 would make use of a proven operational and maintenance program for SHMS units and/or inlet filters, but for 244-A and 244-S the potential for substantial corrective maintenance exists should the necessary pump pit nozzle jumpers fail.

Even with periodic sampling evolutions, Alternative \#1 presents the lowest potential for significant increase in operational and maintenance activities.

\subsection{SUMMARY AND CONCLUSIONS}

A summary of the evaluation is presented in Table 7 below.

Alternative \#1 ranks highest when evaluated and weighed against the selected decision criteria. This alternative provides the capability to conduct periodic sampling and monitoring for flammable gas concentration during routine and long-duration operations using a Combustible Gas Meter, a Flammable Gas Monitor, or a portable SHMS unit.

Alternative \#4 ranks second highest when evaluated and weighed against the decision criteria. This alternative provides both increased airflow input to the tank and measurement of the minimum DCRT tank ventilation rate. This is accomplished by measurement of air through the inlet system. Therefore further assurance can be achieved that levels of flammable gas concentrations are controlled as a result of adequate tank air exchange.

Alternative \#2 ranks third when evaluated and weighed against the decision criteria. This alternative provides direct and continuous measurement of flammable gas concentrations within the tank vapor space, but it does not provide additional airflow capacity to improve the tank breathing rate.

Alternative \#3 ranks fourth when evaluated and weighed against the decision criteria. This alternative provides the ability to measure the amount of air exiting the DCRT storage tank. However, uncertainties exist that sufficient airflow (air infiltration rate) can be maintained within vacuum limits in order to maintain Flammable Gas Levels below $25 \% \mathrm{LFL}$. Alternative \#3 will require access to contaminated filter pits. This adds additional burden to maintenance activities and increases personnel exposure.

Alternative \#5 ranks fifth when evaluated and weighed against the decision criteria. This alternative will provide increased airflow input to the tank, measurement of the minimum DCRT tank ventilation rate (through measurement of air flow through the inlet system), and continuous monitoring of flammable gas concentrations within the tank vapor space. This alternative requires the use of multiple tank penetrations. 


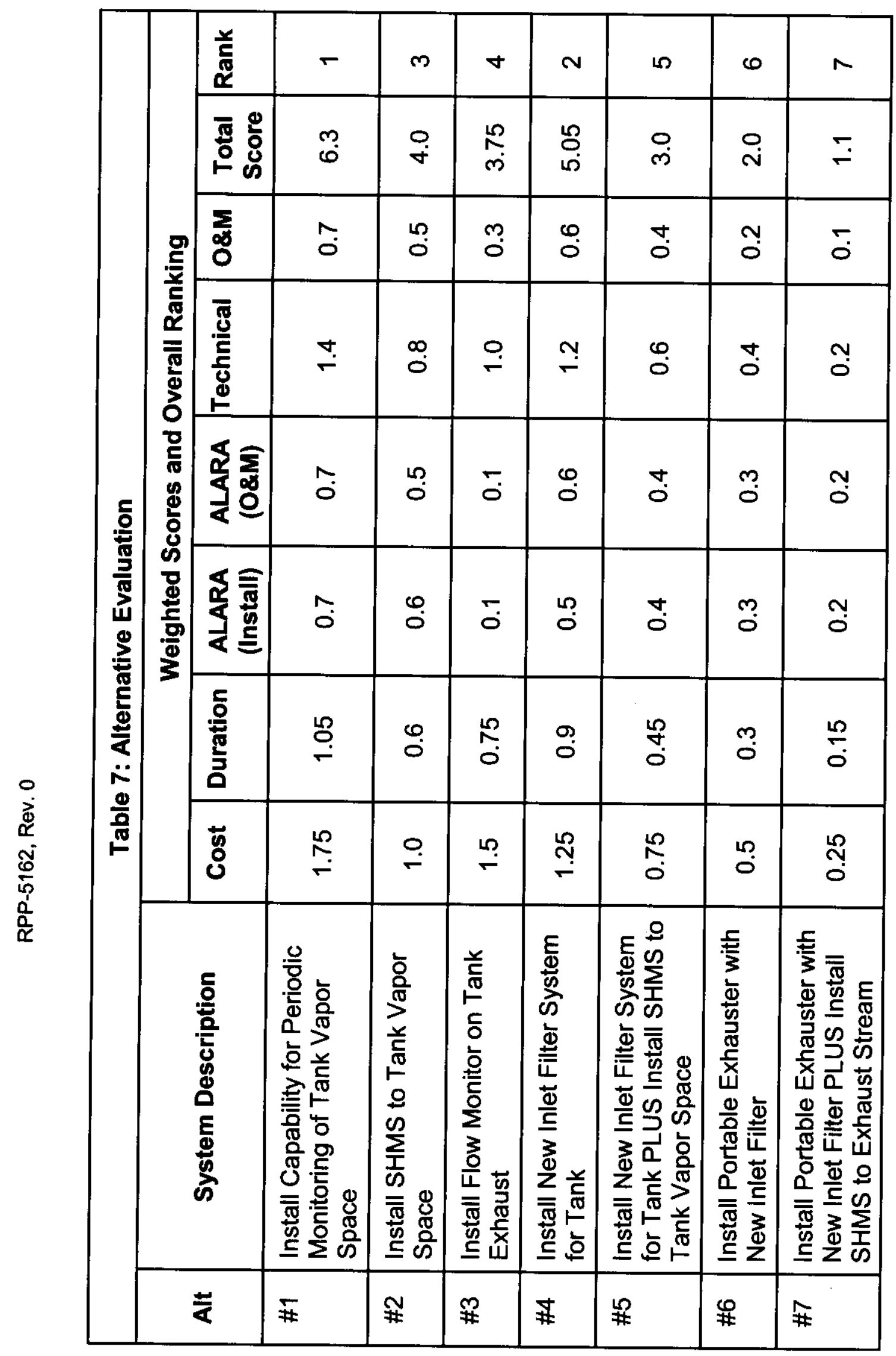


Alternatives \#6 and \#7 rank sixth and seventh, respectively, when evaluated and weighed against the decision criteria. Each of these alternatives will provide both direct airflow to the DCRT tank and direct measurement of the DCRT tank ventilation rate through the portable exhauster stack. Therefore levels of flammable gas concentrations can be controlled. Also, both these alternatives provide independent pathways and control for the annulus and primary (tank) exhaust streams. Additionally, Alternative \#7 provides continuous measurement of flammable gas concentration on the primary (tank) exhaust stream with use of a SHMS unit. However these alternative have significantly elevated cost associated with them when compared with the other alternatives, and they both require the identification and use of multiple tank penetrations.

\subsection{REFERENCES}

Bauer, 1998

Bauer/Hedengren, 1999

Hedengren, et al, 1997

Noorani, 1998

H-2-38214, Rev. 4

H-2-71047, Rev. 6

H-2-73838, Rev. 9

ER-3641-1
HNF-2543, Test Plan for Headspace Gas Concentration Measurements and Headspace Ventilation Rate Measurements for DCRTs 241-A-244, 241-BX-244, 241-S244, and 241-TX-244

HNF-2923, Headspace Gas Concentration Measurements and Headspace Ventilation Rate Measurements for DoubleContained Receiver Tanks 241-A-244, 241-BX-244, 241-S244 , and 241-TX-244

HNF-SD-WM-CN-118, Rev 0, Calculation of Flammable Gas Mixtures in Double-Contained Receiver Tanks

HNF-SD-WM-TSR-006, Tank Waste Remediation System Technical Safety Requirements

Ventilation Airflow and Control Diagram and Schedule Ventilation Airflow and Control Diagram and Schedule Ventilation Airflow and Control Diagram and Schedule Diagram and Schedule Diagram and Schedule

244-U DCRT UPGRADE/ER3641 
RPP-5162, Rev. 0

\section{APPENDIX A}

FIGURES 

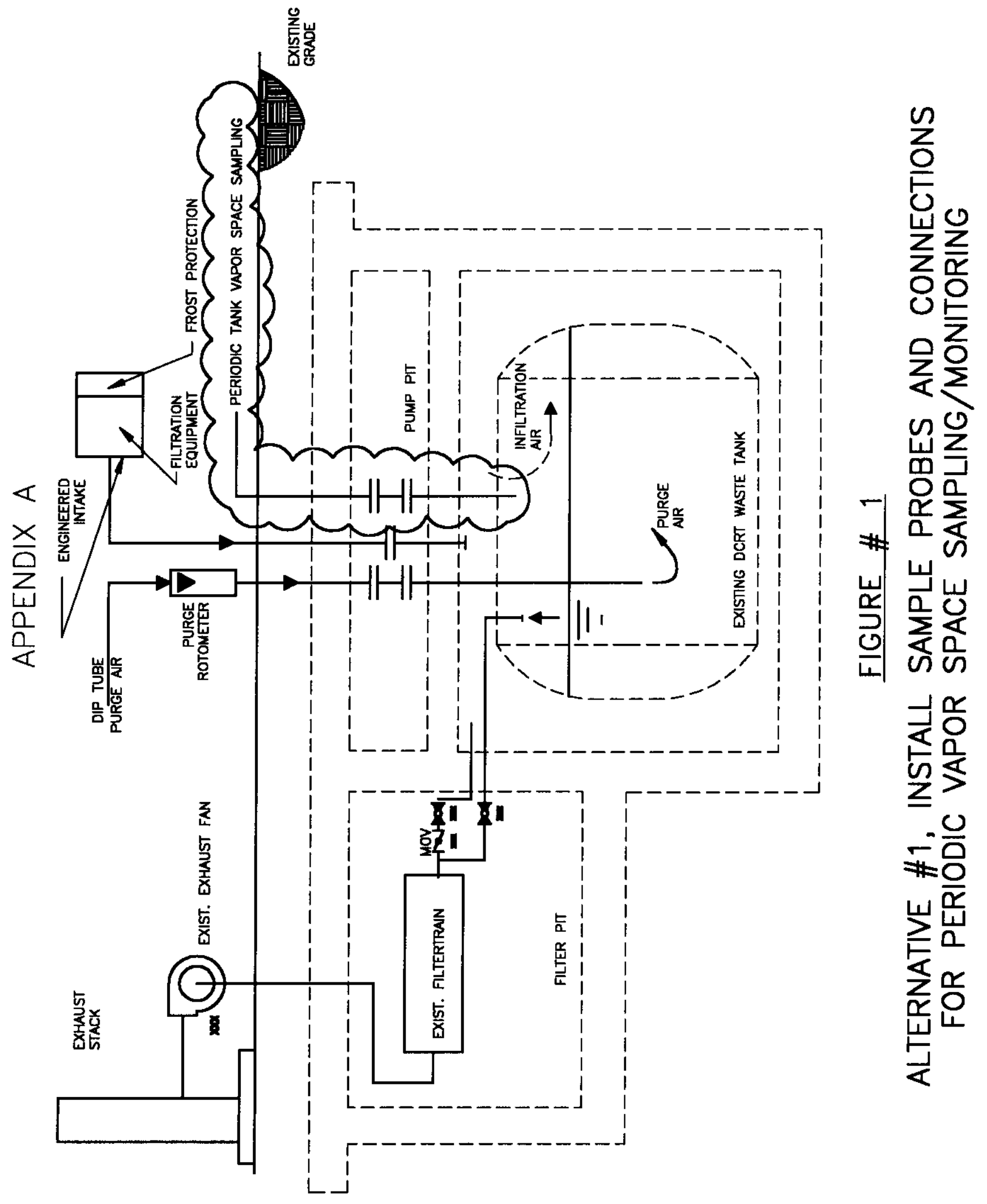


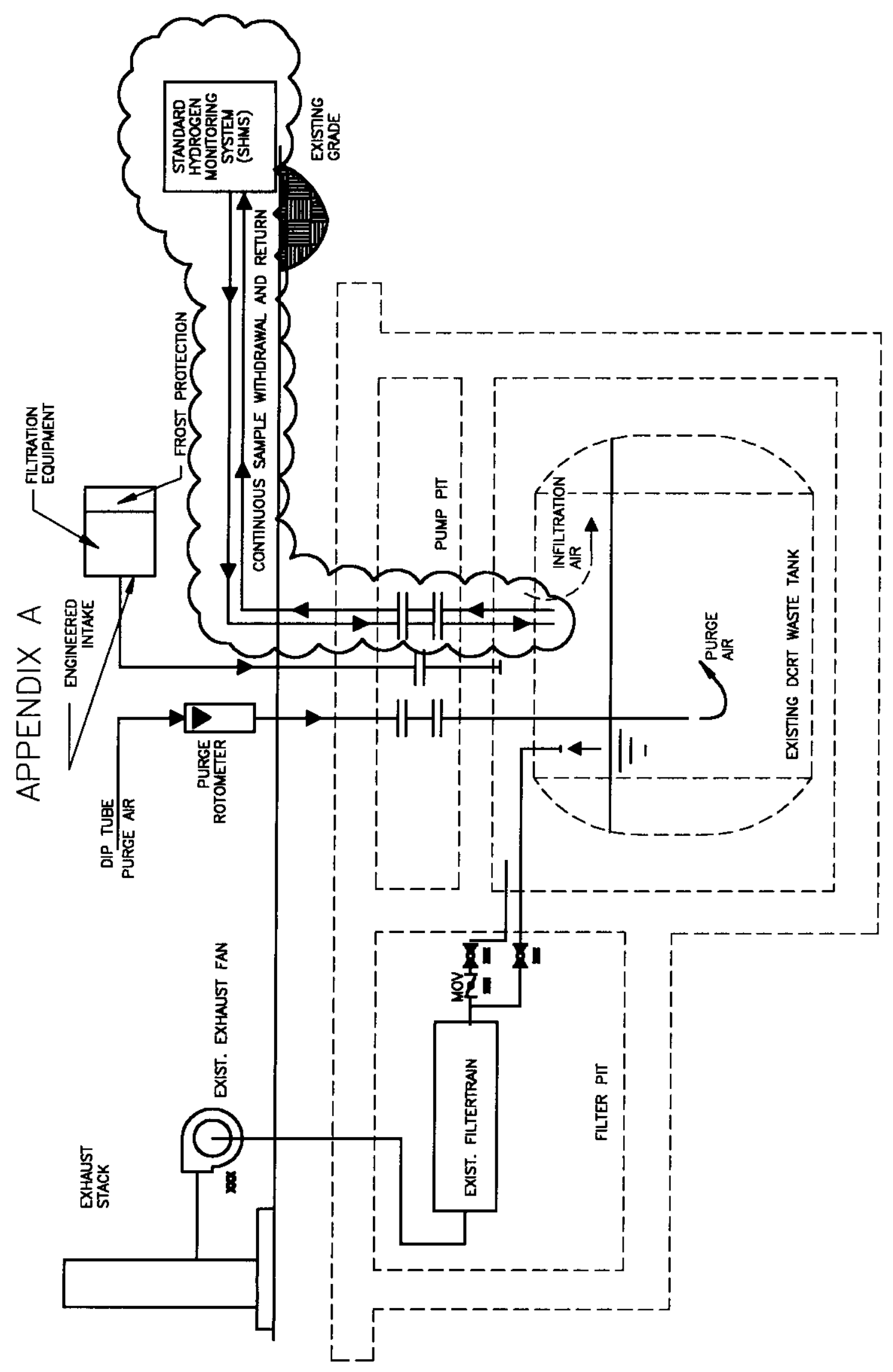




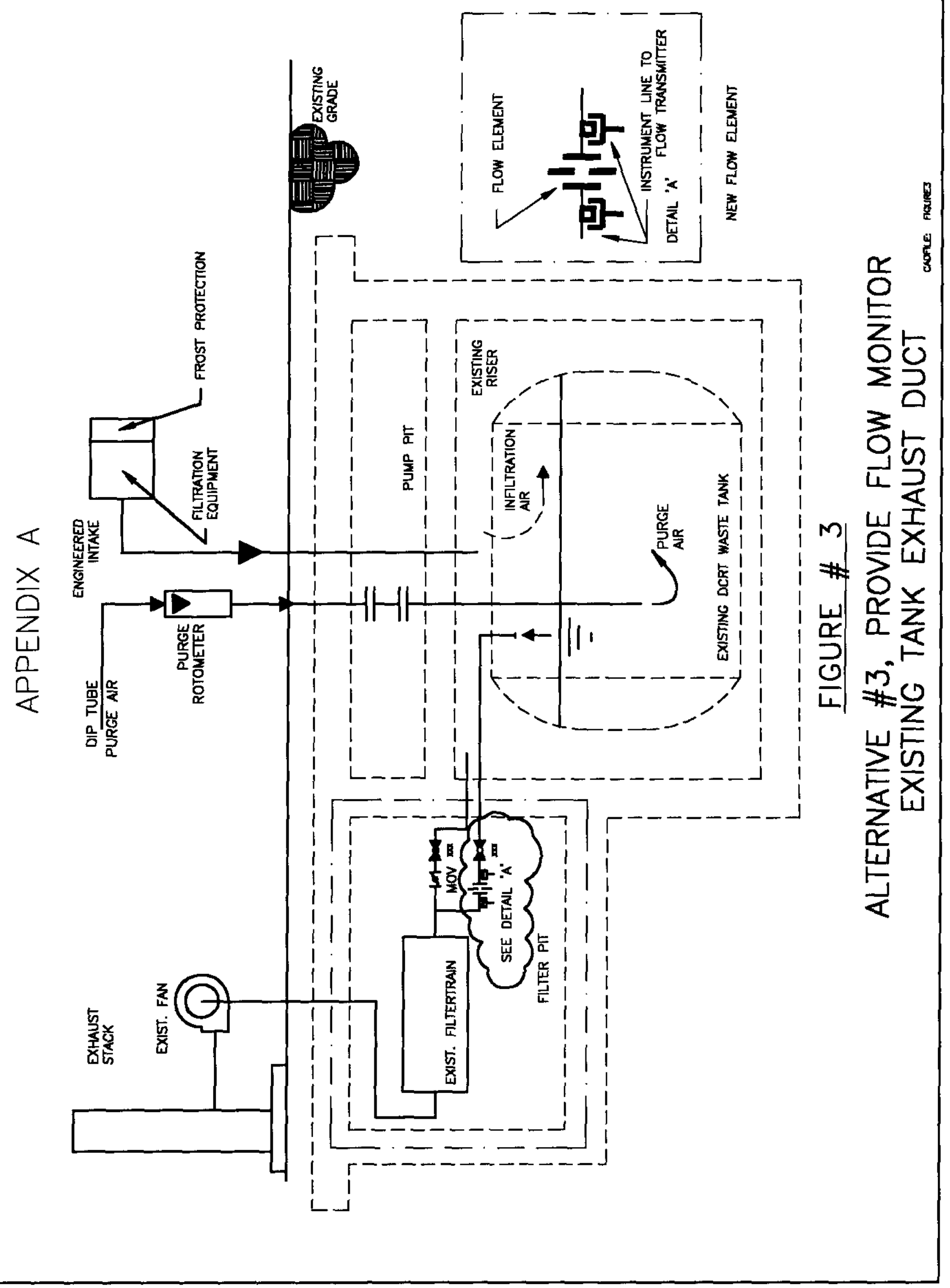




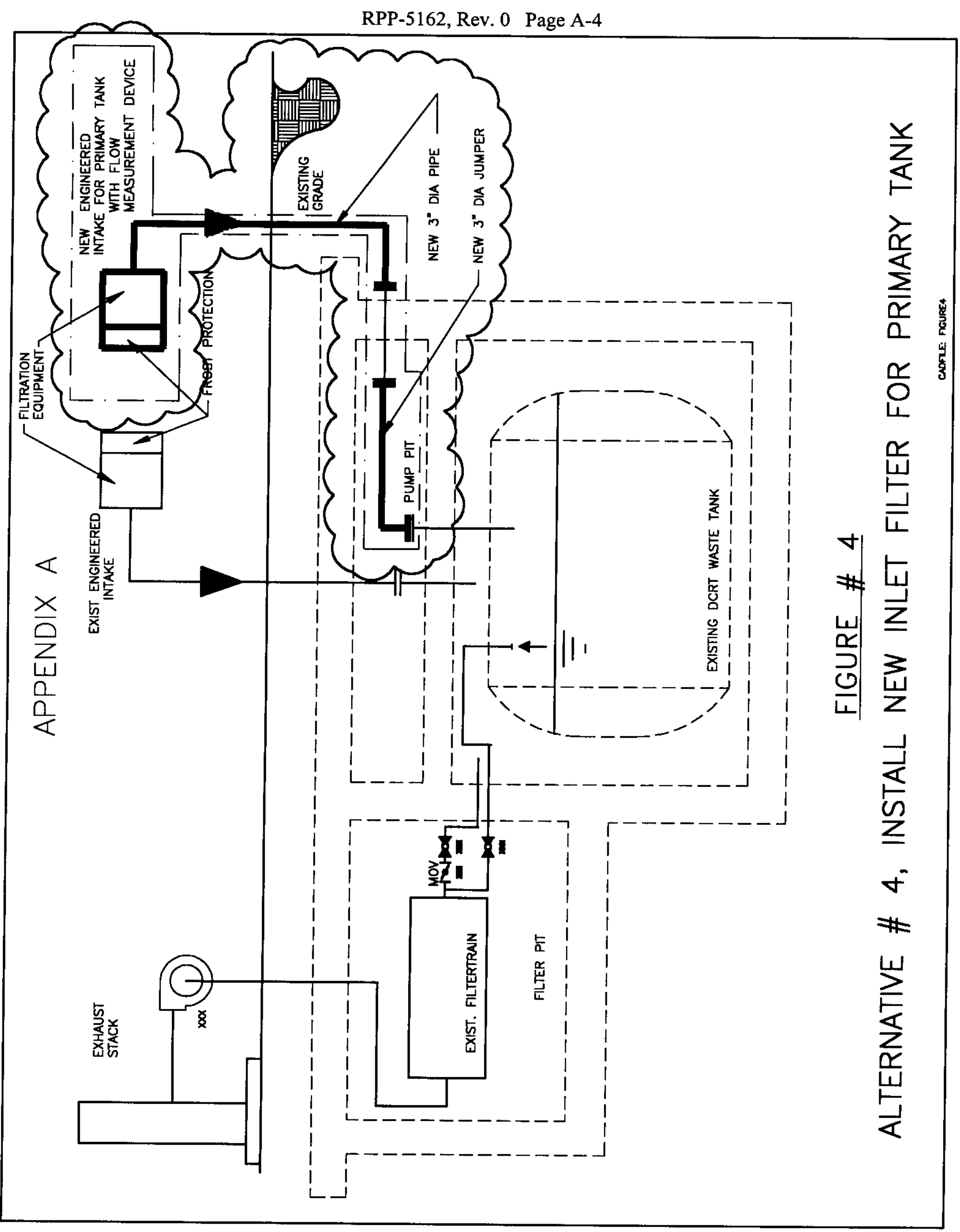


RPP-5162, Rev. 0 Page A-5

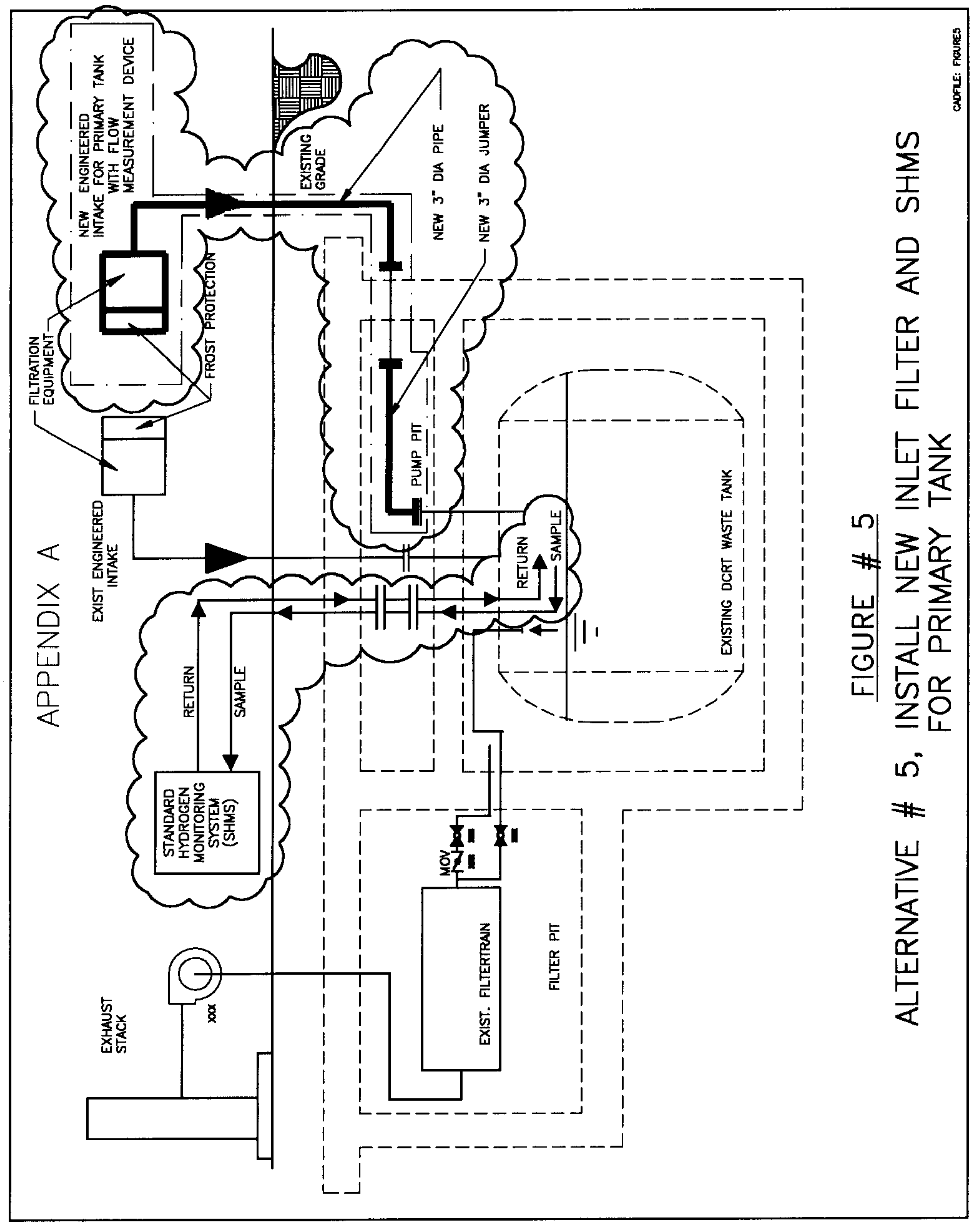


RPP-5162, Rev. 0 Page A-6

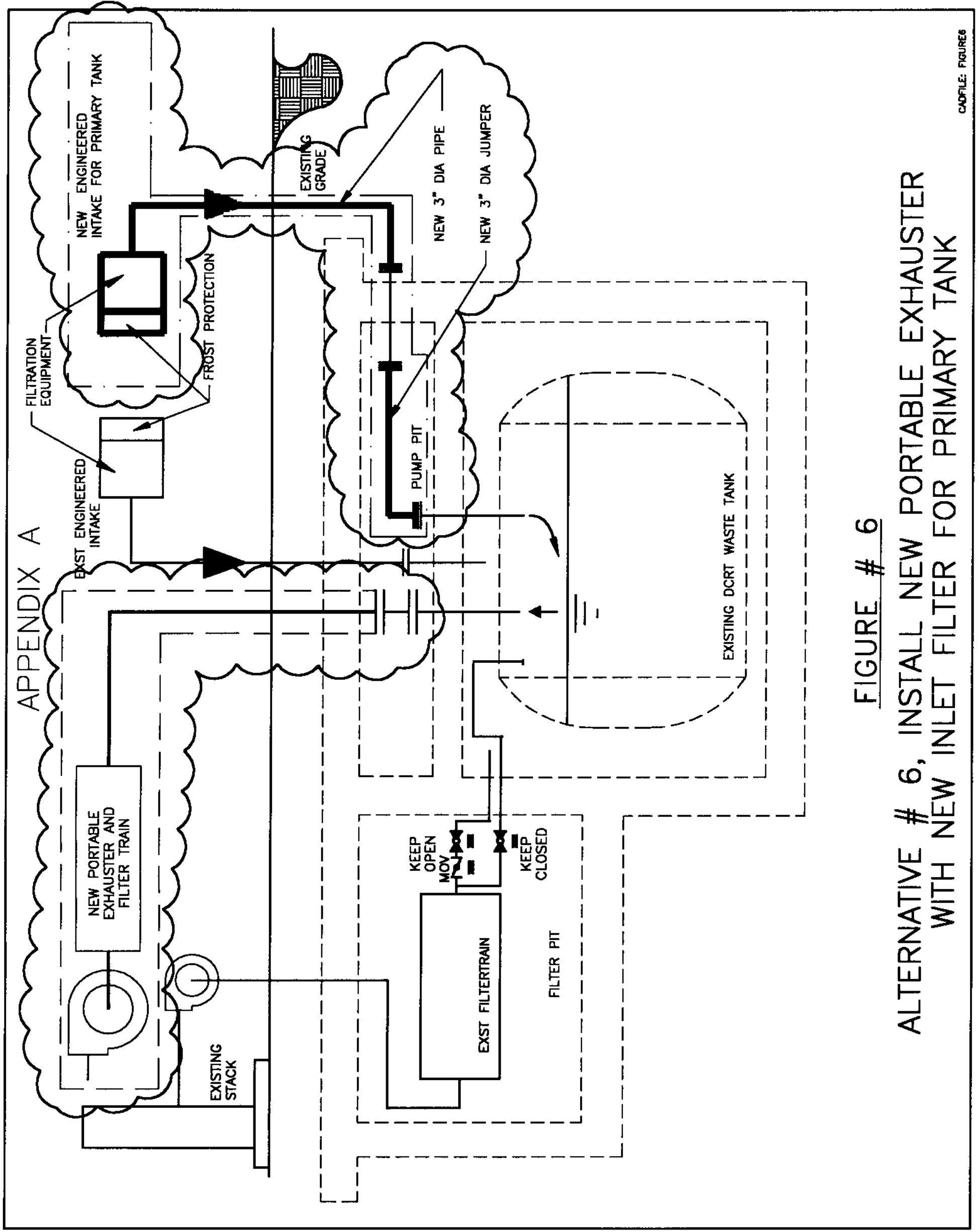


RPP-5162, Rev. 0 Page A-7

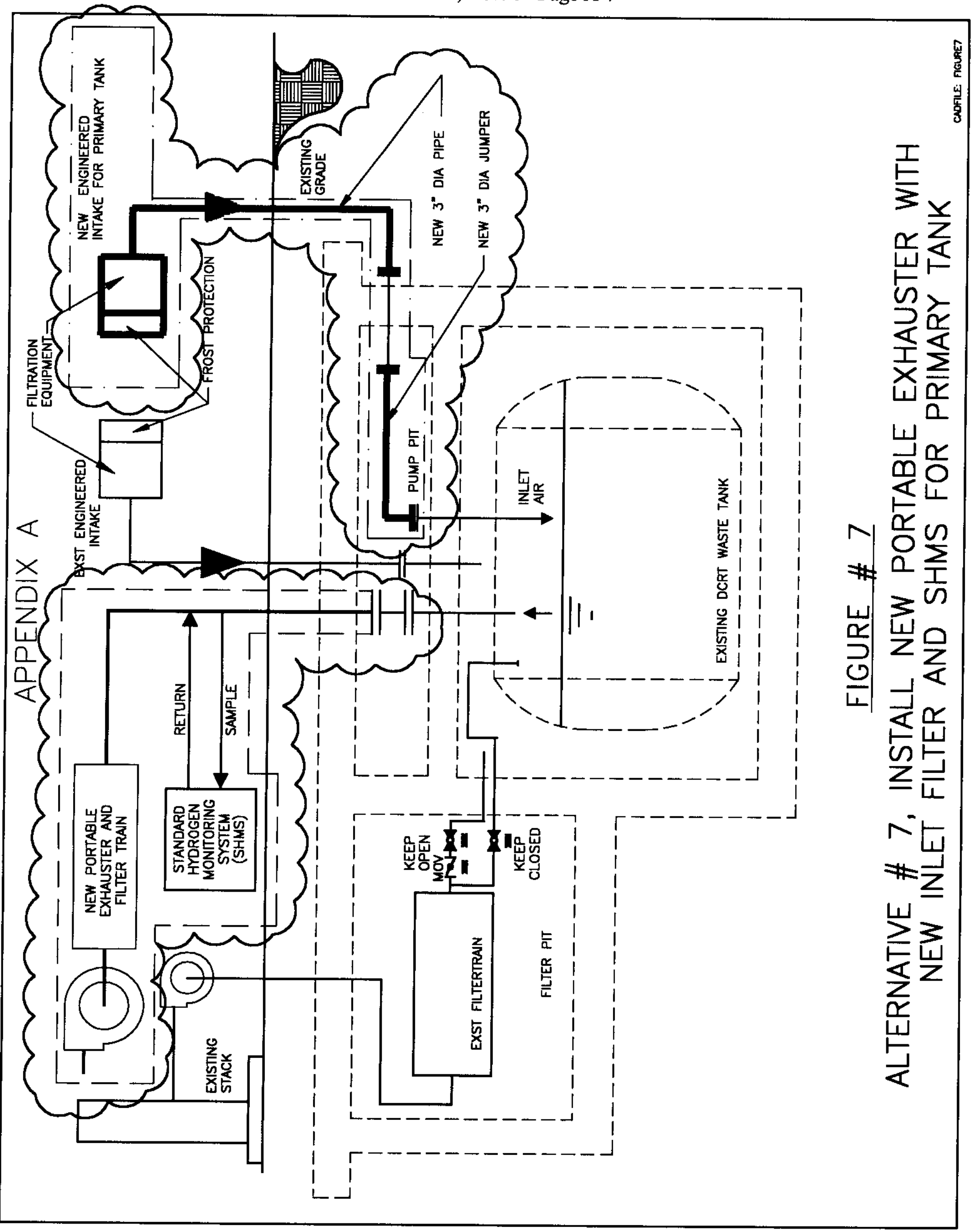




\section{DISTRIBUTION SHEET}

To

LMHC Safety Analysis (74FOO)

Project Title/Work Order

RPP-5162,Rev.0, "Evaluation of Flammable Gas Monitoring And Ventilation System Alternatives For Double-Contained Receiver Tanks.

\begin{tabular}{|c|c|c|c|c|c|}
\hline Name & MSIN & $\begin{array}{c}\text { Text } \\
\text { With All } \\
\text { Attach. }\end{array}$ & Text Only & $\begin{array}{c}\text { Attach./ } \\
\text { Appendix } \\
\text { Only }\end{array}$ & $\begin{array}{c}\text { EDT/ECN } \\
\text { Only }\end{array}$ \\
\hline D.G. Baide & S5-05 & $\mathrm{x}$ & & & \\
\hline A.H. Friberg & $R 1-56$ & $\mathrm{x}$ & & & \\
\hline R.D. Gustavson & $R 1-56$ & $\mathrm{x}$ & & & \\
\hline G.D. Johnson & $R 1-44$ & $\mathrm{x}$ & & & \\
\hline T.D. Kaiser & $\mathrm{T} 4-07$ & $\mathrm{x}$ & & & \\
\hline P.F. Kison & $\mathrm{T} 4-07$ & $\mathrm{x}$ & & & \\
\hline L.E. Kripps & $\mathrm{R} 1-44$ & $\mathrm{x}$ & . & & \\
\hline J.R. Kriskovich & $R 1-56$ & $\mathrm{x}$ & & & \\
\hline K.J. Hull & $\mathrm{T} 4-07$ & $\mathrm{x}$ & & & \\
\hline R.E. Larson & $\mathrm{T} 4-07$ & $\mathrm{x}$ & & & \\
\hline R.W. Reed & $\mathrm{T} 4-07$ & $\mathrm{x}$ & & & \\
\hline D.B. Smet & $R 1-56$ & $\mathrm{x}$ & & & \\
\hline R.S. Nicholson & S5-05 & $\mathrm{x}$ & & & \\
\hline J. Lohrasbi & S5-05 & $\mathrm{x}$ & & & \\
\hline D.H. Shuford & $R 1-56$ & $x$ & & . & \\
\hline & & & & & \\
\hline & & & & & \\
\hline & & & & & \\
\hline & & & & & \\
\hline & & & & & \\
\hline & & & & & \\
\hline & & & & & \\
\hline & & & & & \\
\hline & & & & & \\
\hline & & & & & \\
\hline & & & & & \\
\hline & & & & & \\
\hline & & & & & \\
\hline & & & & & \\
\hline & & & & & \\
\hline & & & & & \\
\hline
\end{tabular}

